\title{
Potentiality of open burnt clay as an adsorbent for the removal of Congo red from aqueous solution
}

\author{
*M. A. Mumin; M. M. R. Khan; K. F. Akhter; M. J. Uddin \\ Department of Chemical Engineering and Polymer Science, Shah Jalal University of Science and Technology, \\ Sylhet-3114, Bangladesh \\ Received 28 February 2007; revised 28 March 2007; accepted 1 August 2007; available online 1 September 2007
}

\begin{abstract}
Open burnt clay was studied as a potential adsorbent for the adsorption of Congo red (a reactive dye) from aqueous solution. The effect of contact time, $\mathrm{pH}$, adsorbent dosage and temperature were studied. It was observed that the amount of Congo red retained increase with decreasing $\mathrm{pH}$ and increasing initial concentration. Removal percentage at $\mathrm{pH} 2$ and 3 are almost same. The adsorption capacity of regenerated burnt clay was showed more than $98 \%$ recovery of the adsorption efficiency of initial virgin adsorbent. The equilibrium data were described well by both Langmuir and Freundlich isotherm model. The adsorption capacity of some natural adsorbents, namely rice husk, wood charcoal, tea waste etc. were also investigated and compared with that of open burnt clay.
\end{abstract}

Key words: Adsorption, wastewater, open burnt clay, Congo red

\section{INTRODUCTION}

One of the major problems concerning textile wastewater is colored effluent. The discharge of color waste is not only damaging the aesthetic nature of receiving streams but also it may be toxic to aquatic life. In addition, color interferes with the transmission of sunlight into the stream and therefore reduces photosynthetic action. According limits of color concentration in effluent are permissible (Metcalf and Eddy, 1991). The color in the effluent is mainly due to unfixed dye. The concentration of unused dyes in the effluent depends upon the nature of dyes and dyeing process underway at the time (McMullan, et al., 2001). Inefficiency of dyeing process results in 10-25\% of all dye stuffs being lost directly to the wastewater (Perineau, et al., 1982). Although the textile dyes contribute only a small portion of the total volume of discharged wastewater after the dyeing process, yet they make it deeply colored (McKay, et al., 1985). The removal of dye in an economic fashion remains an important problem. Considerable work has been carried out on the removal of dye from wastewater (Perineau, et al., 1982; McKay, et al., 1985; Gupta, 1985; Khattri, 2000; Low, et al., 2000; Liversidge, et al., 1997; Choy, et al., 1999, Asilian, et al., 2006). Water insoluble dyes (e.g. disperse and vat dyes) generally exhibit good ×*Corresponding Author Email: mumin-cep@sust.edu Tel.: +880 821714 479; Fax: +880 821715257 exhaustion properties i.e. most of the dye bonds to the fibre and have been reported to be removed by physical means such as flocculation. When effluents containing these classes of dyes are discharged to a conventional sewage treatment works most of the color is removed by adsorption on biomass. However since the introduction of water soluble dyes (reactive dyes), which are extensively used in the industry, conventional biological treatment processes are no longer able to achieve adequate color removal. Adsorption appears to offer the best prospects over all the other techniques (Robinson, et al., 2001; Kamel, et al., 1991; Keith, et al., 1999; McKay, 1981). The most widely used physical method for dye removal is activated carbon (Nasser and El-Geundi, 1991, Molla and Robinson, 1996). Synthetic clays showed a high adsorption for reactive dyes, furthermore, the adsorption capacity for this adsorbent exceeded or almost same that of activated carbon (Lambert, et al., 1997, Sethuraman and Raymahashay, 1985, Singh, et al., 1984). A number of biological adsorbents have also been investigated for the removal of reactive dyes, these include amongst others; apple pomace and wheat straw (Robinson, et al., 2002), corncob and barley husk (Robinson, et al., 2001), maize cob, wood and rice hull (Low and Lee, 1997). These adsorbents were found to be efficient in binding with basic dyes rather than acid 
dyes. In this work the adsorption capacity for reactive dye Congo red was determined using open burnt clay. Open burnt clay was selected because of its high adsorption capacity for a large number of contaminants in aqueous solution. The parameters that influence adsorption such as dye initial concentration, contact time, solution $\mathrm{pH}$ and adsorbent dose were investigated. Adsorption capacity of regenerated open burnt clay was compared with that of fresh adsorbent. The removal of the dye from aqueous solution by some natural adsorbents such as tea waste, wood charcoal, rice husk etc was also studied.

This research work has been done at the Research Laboratories, Department of Chemical Engineering and Polymer Science at the Shah Jalal University of Science and Technology, Sylhet-3114, Bangladesh during February-July 2005.

\section{MATERIALS AND METHODS}

Soil (24.76\% $\left.\mathrm{Fe}_{2} \mathrm{O}_{3}, 5.75 \% \mathrm{Al}_{2} \mathrm{O}_{3}, 58.29 \% \mathrm{SiO}_{2}\right)$ (Sadi and Alam, 1997) collected from the hilly sites of Shah Jalal University of Science and Technology, Sylhet, Bangladesh, was washed with distilled water three times to free it from pebbles and other unexpected particles. The residue was then dried at $105^{\circ} \mathrm{C}$ for an hour. A desired amount of dry clay was placed in a crucible and burned with the help of a gas burner for fifteen minutes which was used as adsorbent. The particle size of adsorbent was 100-400 mesh and bulk density was measured as $1.2 \mathrm{~g} / \mathrm{cm}^{3}$. The reactive dye Congo red (MERCK, Germany) was used as adsorbate. Stock solution of Congo red was made using double distilled water. All working solutions were prepared by diluting the stock solution with double distilled water. The $\mathrm{pH}$ adjustments were made with $\mathrm{HCl}$ or $\mathrm{NaOH}$ solutions. The concentrations of dye were determined spectrophotometrically (UV-spectrophoto-meter, Model: UV-1601, Shimadzu, Japan) by monitoring the absorbance at $498 \mathrm{~nm}$ for neutral $\mathrm{pH}$ and at $558 \mathrm{~nm}$ for $\mathrm{pH}$ in acidic range, where maximum absorbances were observed. Batch sorption tests were done at $26 \pm 2{ }^{\circ} \mathrm{C}$ temperature using a flash shaker at $350 \mathrm{rpm}$ in $250 \mathrm{~mL}$ conical flasks. In the adsorption isotherm tests, $1.5 \mathrm{~g}$ adsorbent was thoroughly mixed into $200 \mathrm{~mL}$ dye solution in the range $40-100 \mathrm{mg} / \mathrm{L}$. The initial $\mathrm{pH}$ was adjusted at 3 by $\mathrm{HCl}$ solution. After the flasks had been shaken for $7 \mathrm{~h}$., the solution was centrifuged for the separation of solid particles before spectrophotometric measurements of dye. Adsorption kinetic tests were done for the initial concentration range 40-100 $\mathrm{mg} / \mathrm{L}$, adsorbent amount $1.5 \mathrm{~g}$ at $\mathrm{pH}=3$. For $\mathrm{pH}$ studies, $1.5 \mathrm{~g}$ adsorbent was thoroughly mixed into $200 \mathrm{~mL}$ dye solution having initial concentration of $50 \mathrm{mg} / \mathrm{L}$. The solution was agitated for $7 \mathrm{~h}$. Shaking time for all cases was $7 \mathrm{~h}$. because at that time system reached to the equilibrium

\section{RESULTS}

The analysis of isotherm data is useful for design purpose. In present study the equilibrium data were treated by Langmuir and Freundlich isotherms. The Langmuir isotherm can be represented by the following equation (McKay, 1981).

$$
\frac{1}{q_{e}}=\frac{1}{K q_{\infty} C_{e}}+\frac{1}{q_{\alpha}}
$$

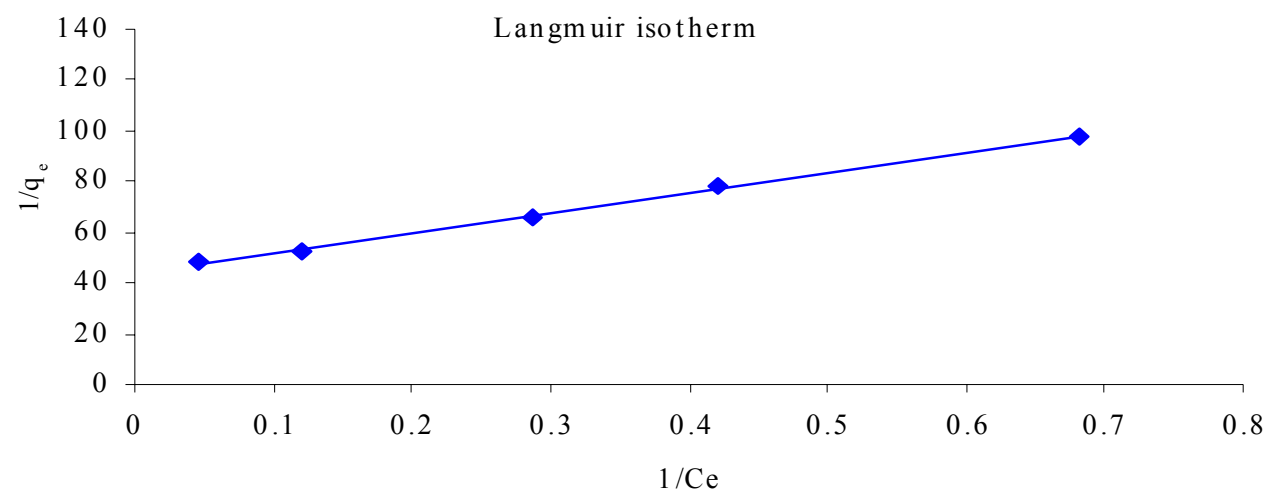

Fig. 1: Langmuir isotherm for Congo red on burnt clay 
where, $q_{e}$ is the amount adsorbed per unit mass of sorbent at equilibrium $(\mathrm{kg} / \mathrm{kg}) ; q_{\alpha}$ is the maximum adsorption capacity $(\mathrm{kg} / \mathrm{kg}) ; \mathrm{C}_{\mathrm{e}}$ is the equilibrium dye concentration $(\mathrm{mg} / \mathrm{L})$ and $\mathrm{K}$ is the adsorption equilibrium constant $\left(\mathrm{m}^{3} / \mathrm{kg}\right)$. The plot of $1 / \mathrm{q}_{\mathrm{e}}$ vs $1 / \mathrm{C}_{\mathrm{e}}$ is linear which show that the adsorption of dye onto burnt clay follows Langmuir isotherm model (Fig. 1). $q_{\alpha}$ and $\mathrm{K}$ were calculated from the slope and intercept of the plot and were found to be $q_{\infty}=22.83 \times 10^{-3} \mathrm{~kg} /$ $\mathrm{kg}$ and $\mathrm{K}=0.55 \times 10^{3} \mathrm{~m}^{3} / \mathrm{kg}$. The Freundlich isotherm was also applied for the adsorption of dye by burnt clay (McKay, 1981). $\log q_{e}=(1 / n) \log C_{e}+\log k_{f}$

where, $q_{e}$ is the amount adsorbed per unit mass of adsorbent at equilibrium $(\mathrm{kg} / \mathrm{kg}) ; \mathrm{C}_{\mathrm{e}}$ is the equilibrium dye concentration of the solution $(\mathrm{mg} / \mathrm{L}) . \mathrm{k}_{\mathrm{f}}$ and $\mathrm{n}$ are the Freundlich constants, $\mathrm{n}$ gives an indication of the favorability and $\mathrm{k}_{\mathrm{f}}\left[\mathrm{kg} / \mathrm{kg}\left(\mathrm{m}^{3} / \mathrm{kg}\right)^{\mathrm{n}}\right]$, the capacity of the adsorbent (Netpradita, et al., 2003). From Fig. 2, it can be seen that the equilibrium data can be fit satisfactorily with Freundlich. The value of $k_{f}$ and $n$ were found to be 0.298 and 3.802 respectively. The value of $n$ lies between 2 and 10, which implies good adsorption (Mc Kay, et al., 1985).

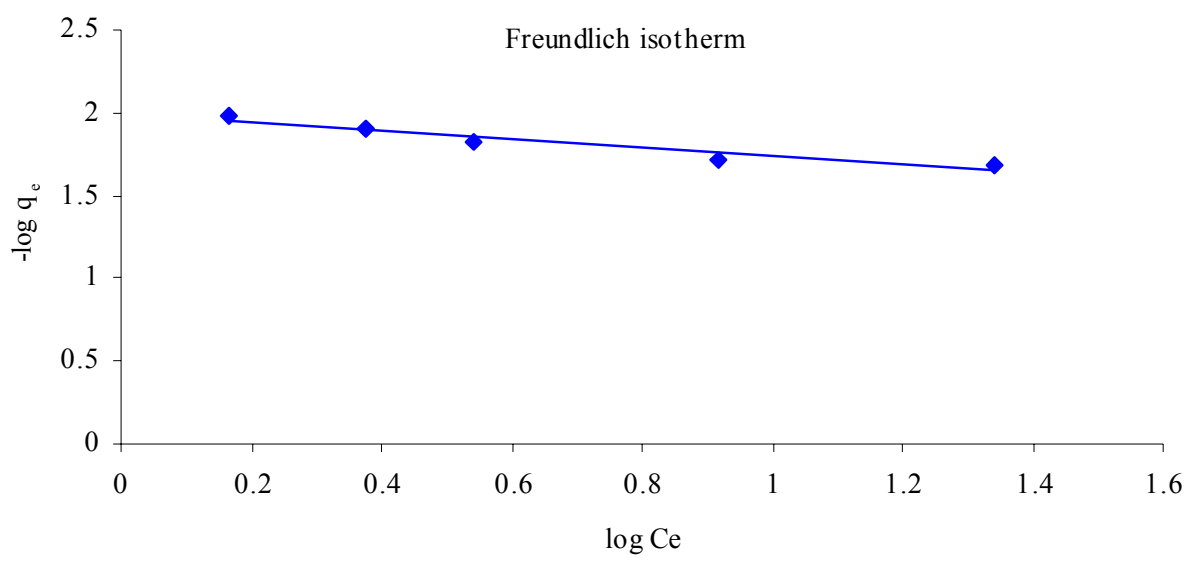

Fig. 2: Freundlich isotherm of Congo red adsorption

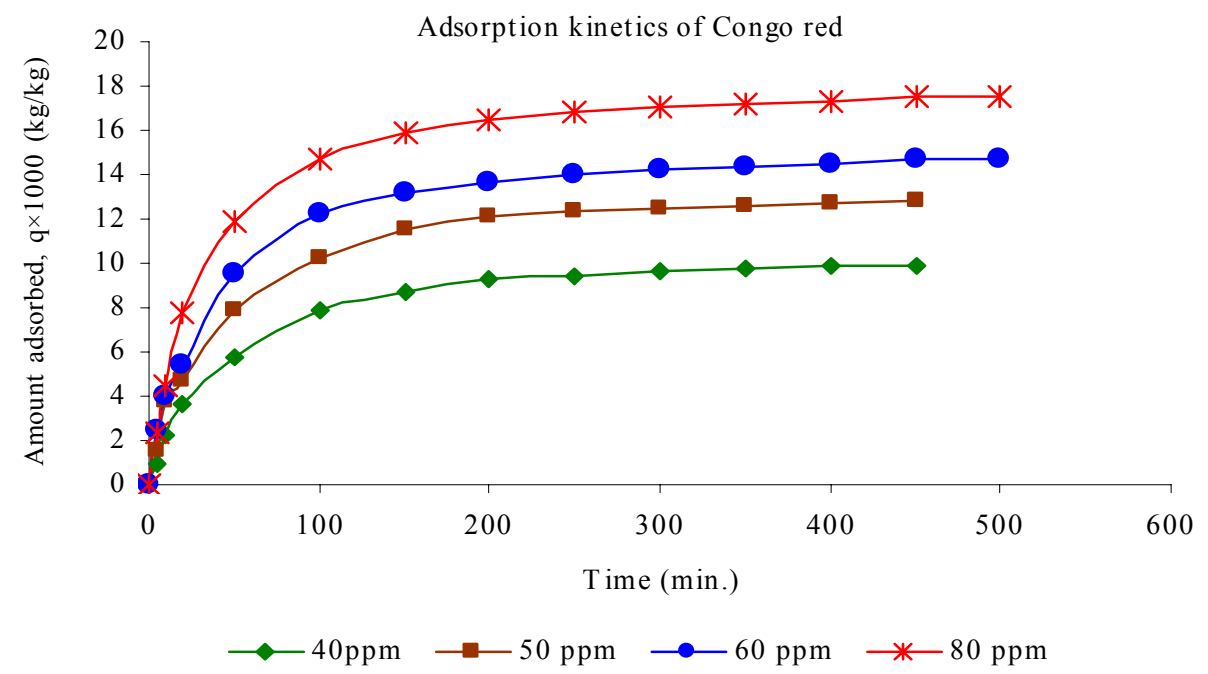

Fig. 3: Adsorption kinetics of Congo red 


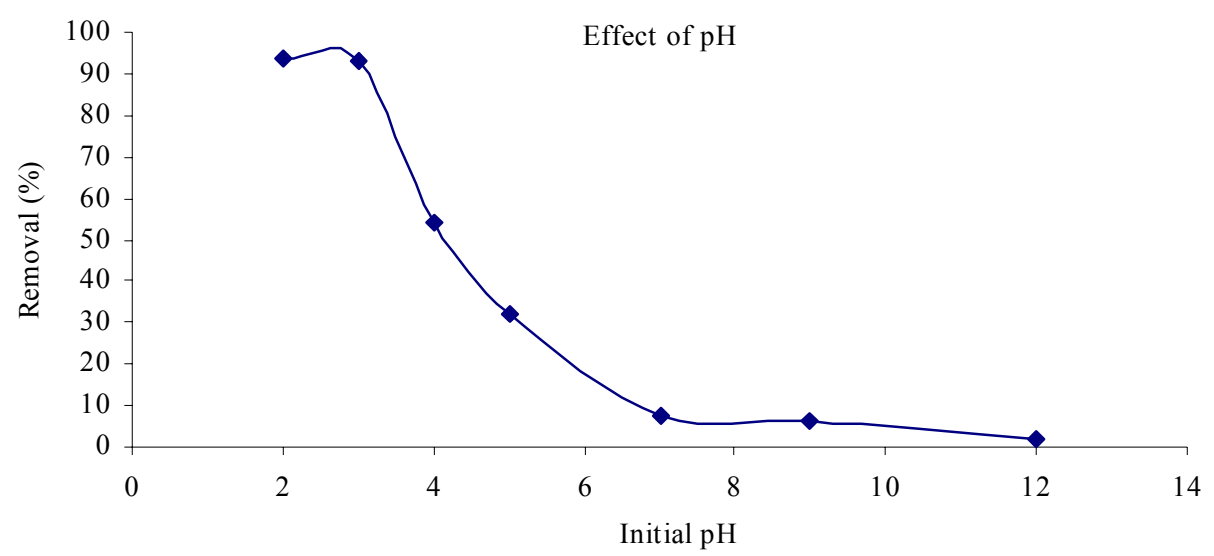

Fig. 4: Effect of $\mathrm{pH}$ on adsorption of Congo red

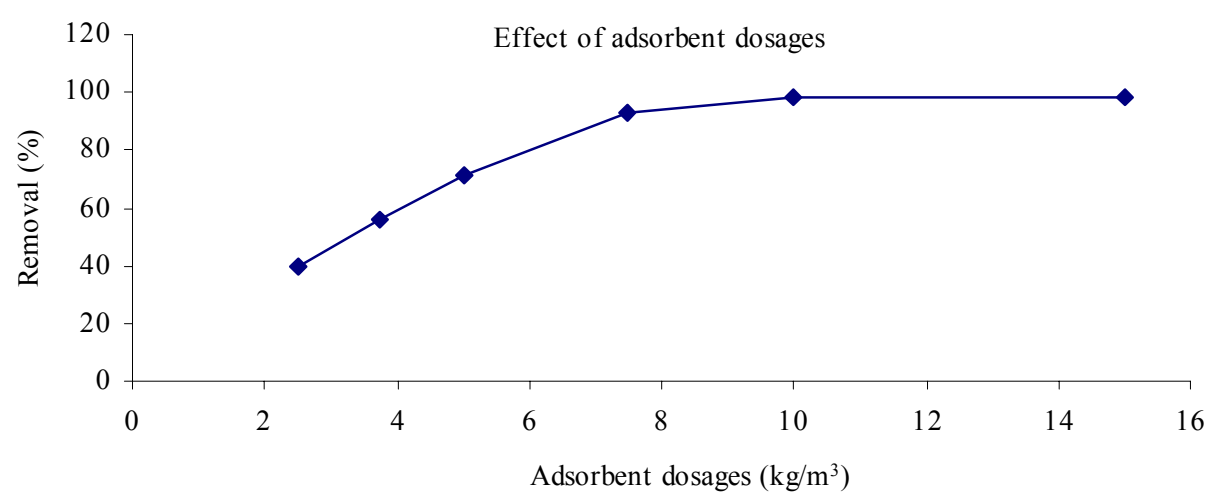

Fig. 5: Effect of adsorption dose on removal of Congo red

Effect of contact time and initial dye concentration on dye removal was investigated using dye concentrations $40-80 \mathrm{mg} / \mathrm{L}$ and $\mathrm{pH}_{\text {in }}=3$. The results are presented in Fig. 3 and show that dye uptake by burnt clay reached equilibrium in approx. 200, 300, 350 and $420 \mathrm{~min}$ for dye concentrations of 40, 50, 60 and 80 $\mathrm{mg} / \mathrm{L}$ respectively. The removal of dye was rapid in the initial stages of contact time and gradually decreased with time until equilibrium. The effect of $\mathrm{pH}$ on Congo red removal was studied at different $\mathrm{pH}$ values. The results are presented in Fig. 4. When $\mathrm{pH}$ of dye solution was increased form 2 to 12 , the percent removal decreased from $94 \%$ to $2 \%$. Influence of adsorbent concentration on the amount of Congo red adsorbed by open burnt clay is shown in Fig. 5. It can be seen that by increasing the adsorbent dose from $0.5-3 \mathrm{gm}$ (for initial dye concentration $50 \mathrm{mg} / \mathrm{L}$, solution volume $200 \mathrm{~mL}$ and at a $\mathrm{pH}=3$ ) the removal efficiency increases. The number of available adsorption sites increases by increasing the adsorbent dose and that results in the increase of removal efficiency. Clay is very much cheap so regeneration is not necessary. In our present study we did the regeneration of used burnt clay to check the adsorption capacity of regenerated burnt clay. The conventional method for regeneration of spent adsorbent is thermal treatment of the sorbed organics in a controlled atmosphere that minimizes the oxidation of the adsorbent particles itself. In our present study the used burnt clay is openly burnt to regenerate and reuse. The adsorption capacity of the regenerated burnt clay was found $0.02038 \mathrm{~kg} / \mathrm{kg}$, i.e. the capacity decreases by calculation is only $1.1 \%$.

\section{DISCUSSION AND CONCLUSION}

Adsorption of Congo red onto burnt clay followed both Langmuir and Freundlich isotherm. The adsorption capacity of burnt clay was $22.83 \times 10^{-3} \mathrm{~kg} /$ $\mathrm{kg}$ adsorbent. 
Table 1: Analysis of Langmuir Isotherm

\begin{tabular}{cccc}
\hline $\mathrm{q} \alpha(\mathrm{mg} / \mathrm{g})$ & $\mathrm{K}(\mathrm{L} / \mathrm{mg})$ & $\begin{array}{c}\text { Initial dye concentration } \\
\mathrm{C} 0 \mathrm{ppm}\end{array}$ & $\mathrm{R}_{\mathrm{L}}$ \\
\hline \multirow{2}{*}{22.86} & \multirow{2}{*}{0.55} & 40 & 0.0435 \\
& & 50 & 0.0351 \\
& & 60 & 0.0294 \\
& & 80 & 0.0222 \\
& & 100 & 0.0179 \\
\hline
\end{tabular}

The essential characteristics of Langmuir isotherm can be express by a dimensional constant called equilibrium parameter, $R_{L}$ (Nasser, 1991) that is defined by,

$$
R_{L}=\frac{1}{1+K C_{0}}
$$

where, $\mathrm{K}$ is the Langmuir constant at $\mathrm{m}^{3} / \mathrm{kg}$ and $\mathrm{C}_{\mathrm{o}}$ is the initial concentration. The value of $R_{L}$ indicates the shape of the isotherm to be either unfavourable $\left(\mathrm{R}_{\mathrm{L}}\right.$ $>1)$, linear $\left(\mathrm{R}_{\mathrm{L}}=1\right)$, favourable $\left(0<\mathrm{R}_{\mathrm{L}}<1\right)$ or irreversible $\left(\mathrm{R}_{\mathrm{L}}=0\right)$. As shown in Table $1, \mathrm{R}_{\mathrm{L}}$ value decreases with the concentration and indicates favorable adsorption for dye on clay. In the Freundlich isotherm, the Freundlich constant $\mathrm{n}$ gives an indication of the favorability. The value of $\mathrm{k}_{\mathrm{f}}$ and $\mathrm{n}$ were found to be 0.298 and 3.802 respectively. The value of $\mathrm{n}$ lies between 2 and 10, which implies good adsorption (Mc Kay, et al., 1985). During Kinetic study it has been seen that the removal of dye was rapid in the initial stages of contact time and gradually decreased with time until equilibrium. This decreasing removal rate towards the end, suggests formation of monolayer coverage of dye molecules on the outer surface of the adsorbent and pore diffusion onto the inner surface of the adsorbent particles through the film due to continuous agitation maintained during the experiments. The rate constant for the adsorption of dye on burnt clay was determined using Lagergren equation (Gueu et al., 2007, Islam et al. 2004).

$$
\log \left(\mathrm{q}_{\mathrm{e}}-q\right)=\log q_{e}-k_{a d} t / 2.303
$$

where, $\mathrm{q}_{\mathrm{e}}$ and $\mathrm{q}$ are the amounts of dye adsorbed $(\mathrm{kg} /$ $\mathrm{kg}$ ) at equilibrium and at time $\mathrm{t}(\mathrm{min})$, respectively and $\mathrm{k}_{\mathrm{ad}}$ is the rate constant of adsorption. The $\mathrm{k}_{\mathrm{ad}}$ values are determined by fitting the kinetic data to Eq.4 and presented Table 2. The rate constant is found to be changed with initial concentration (Fig. 7). It may be concluded from the data fitting in the rate expression that the reaction taking place is of the first order. Sorption of Congo red onto burnt clay is $\mathrm{pH}$ dependent and optimum $\mathrm{pH}$ was 3 . The kinetic data reveals that
Table 2: Rate constant at different initial concentrations

\begin{tabular}{cc}
\hline $\begin{array}{c}\text { Initial Concentration, } \\
\left(\mathrm{kg} / \mathrm{m}^{3}\right)\end{array}$ & $\begin{array}{c}\text { Lagergren rate constant, } \\
\mathrm{k}_{\mathrm{ad}} / \mathrm{min}\end{array}$ \\
\hline 0.05 & 0.0443 \\
0.1 & 0.0344 \\
0.15 & 0.032 \\
0.2 & 0.0422 \\
\hline
\end{tabular}

the adsorption takes place follows the first order reaction kinetics. The adsorption capacity of regenerated burnt clay was $20.38 \times 10^{-3} \mathrm{~kg} / \mathrm{kg}$, which is almost similar with that for initial virgin adsorbent. From the $\mathrm{pH}$ study it can be concluded that in acidic media the dye removal percentage is higher. The decrease in adsorption with $\mathrm{pH}$ may be explained on the basis of aquacomplex formation and subsequent acid-base dissociation at solid solution interface. Any oxide surface creates a charge (positive or negative) on its surface (Netpradita, et al., 2003). This charge is proportional to the $\mathrm{pH}$ of the solution that surrounds the oxide particle. The structure of Congo red and the change in color from red to blue in presence of mineral acid is due to the resonance hybrid of (1) and (2) structures given below (Rahman, et al., 1999). The structure of Congo red and the change in colour from red to blue in presence of mineral acid is due to the resonance hybrid (Rahman, et. al., 1999). Congo red contains an azo $(-\mathrm{N}=\mathrm{N}-)$ chromophore and an acidic auxochrome $\left(-\mathrm{SO}_{3} \mathrm{H}\right)$ associated with the benzene structure. Congo red is also called acidic azo dye. Azo structure is more important because of its high ability to impart color to the compound. Structure (2) in acid media, posses two ${ }^{+} \mathrm{NH}_{2}$ groups, which shows affinity to attract negatively charged silica /silicate anion in clay. Lower $\mathrm{pH}$, it is usual that clay shows a great adsorptive power to Congo red. It can also be seen that by increasing the adsorbent dose from $0.5-3 \mathrm{gm}$ the removal efficiency increases. The number of available adsorption sites increases by increasing the adsorbent dose and that results in the increase of removal efficiency. Another reason may be due to the aggregation/agglomeration of adsorbent particles at higher concentration. Such aggregation would lead to decrease in total surface area of soil particles available to Congo red adsorption and an increase in diffusional path length (Al-Degs, et al., 2000). The particle interaction action brought about by high sorbet concentration may also desorb some of the adsorbate which is only loosely and reversibly bond to the carbon surface. The data can also be used to derive a mathematical relationship to relate the Congo red removal to the adsorbent dose. 


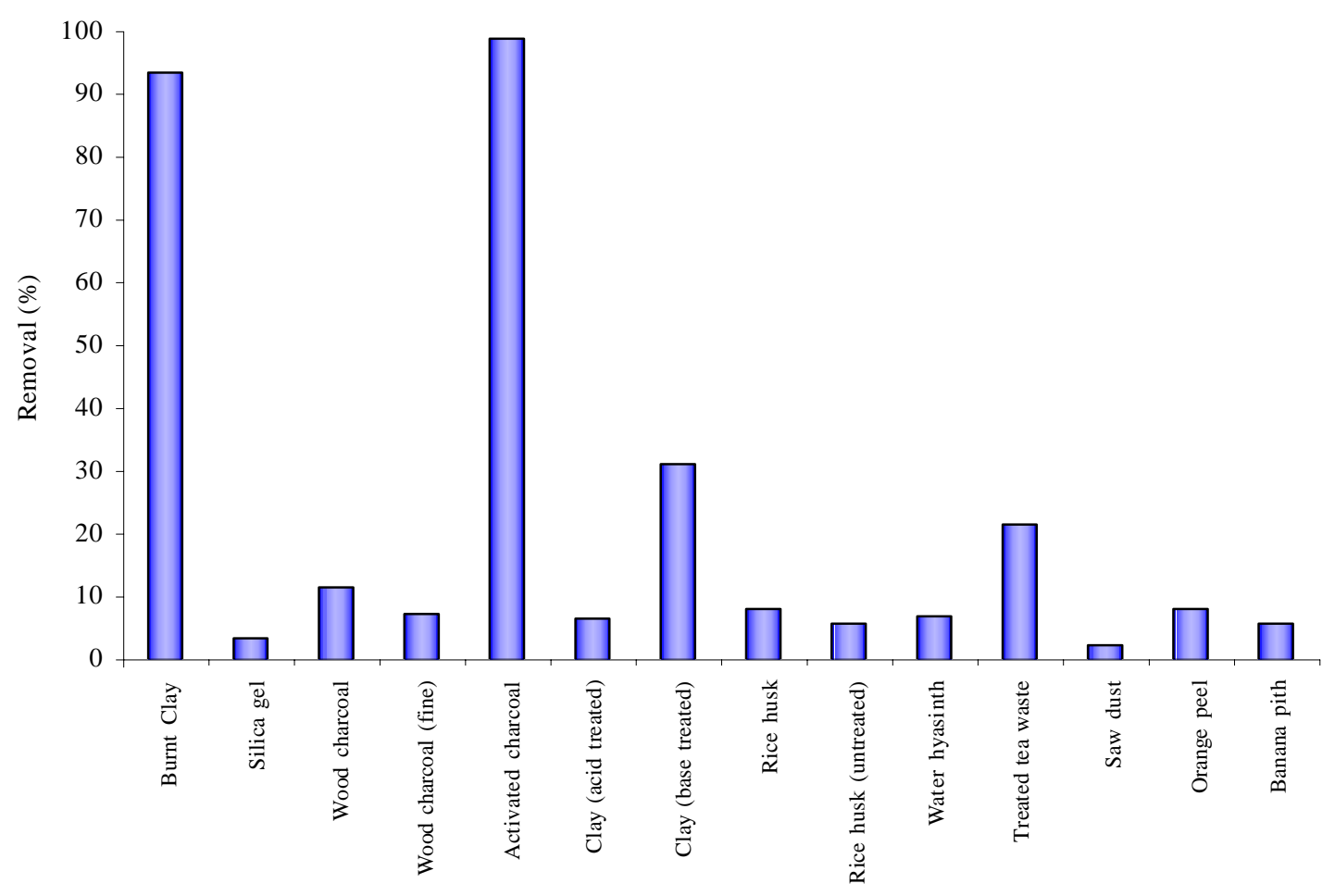

Fig. 6: Removal of Congo red by different adsorbents

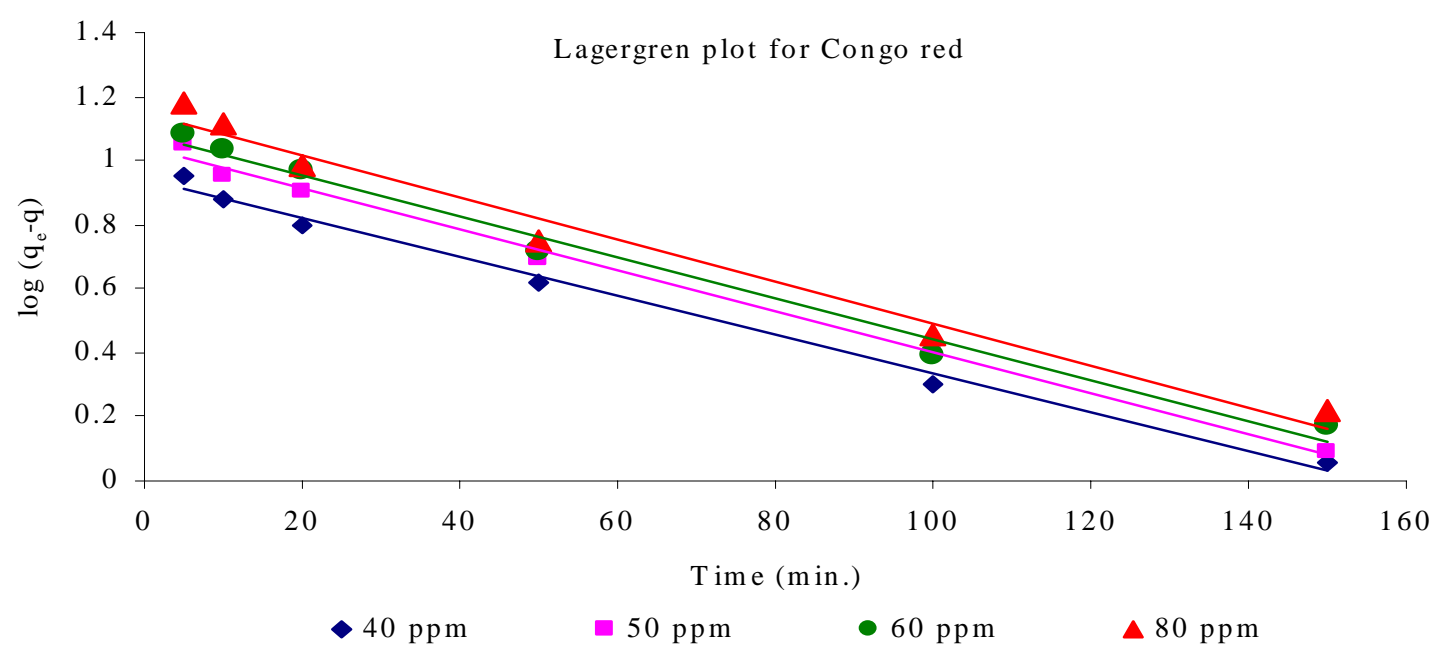

Fig. 7: Lagergren plot of Congo red for different initial concentration 
This relationship, for which the correlation coefficient (R) was 0.913 , is

$$
R=\frac{m_{s}}{59 \times 10^{-7}+81.5 \times 10^{-4} m_{s}}
$$

This equation can be used to predict the percentage Congo red removal for any adsorbent dose with in the test limits to the experimental conditions. The removal efficiency was studied for an initial dye concentration of $50 \mathrm{mg} / \mathrm{L}$ and different adsorbent doses. Optimum results are shown in Fig. 6. It is evident that the congo red removal by activated charcoal approaches to almost $100 \%$, but it is expansive, can not be disposed in the environment and regeneration is essential. Tea waste and base treated clay showed almost $40 \%$ removal of Congo red, where as the open burnt clay showed comparable results with that of activated charcoal. The results obtained in this study clearly demonstrated the potentiality of burnt clay for the removal of Congo red from aqueous solution. It is also evident that activated charcoal is most superior adsorbent but it is expansive, can not be disposed in the environment and regeneration is essential. On the other hand, industrially or in case of large scale operation regeneration of adsorbent by desorption is not feasible. Therefore burnt clay could be the only alternative of activated charcoal in this process.

\section{ACKNOWLEDGEMENTS}

Authors are indebted to the Shah Jalal University of Science and Technology, Sylhet, Bangladesh for their support.

\section{REFERENCES}

Al-Degs, Y.; Khraisheh, M.A.; A.S.J.; Ahmed, M.N., (2000). Evaluation of activated carbon adsorbents for the removal of textile reactive dyes from wastewater. Jordan International Chemistry Engineering Conference, 1, 159-167.

Asilian, H.; Moradian fard, Sh.; Rezaei, A.; Mortazavi, S.B.; Khavanin, A., (2006). The removal of color and COD from wastewater containing water base color by coagulation process, Int. J. Environ. Sci. Tech., 3(2), 153-157.

Choy, K.K.H.; McKay, G.; Porter, J.F., (1999). Sorption of acid dyes from effluent using activated carbon. Resour. Conserv. Recycl., 27, 57-62.

Gupta, M.P.; Bhattacharya, P.K., (1985). Studies on color removal from bleach plant effluent of a craft pulp mill. J. Chem. Tech. Biotech., 35(B), 23-28.

Gueu, S.; Yao, B.; Adouby, K.; Ado, G., (2007). Kinetics and thermodynamics study of lead adsorption on to activated carbons from coconut and seed hull of the palm tree, Int. J. Environ. Sci. Tech., 4 (1), 11-17.
Islam, M.A.; Khan, M.M.R.; Mozumder, M.S.I., (2004). Adsorption equilibrium and adsorption kinetics: A unified Approach. J. Chem. Eng. Tech., 27, 1095-1098.

Kamel, M.M. Magda, M. Kamel, B.M. Youssef Waly, A.(1991). Adsorption of direct dyes by cellulose derivatives. Am. Dye Rep. 34, 50-57.

Keith, K.H.C.; Gordon, M.; John, F.P., (1999). Sorption acid dyes from effluent using activated carbon. Resour. Conserv. Recycl. 27, 57-62.

Khattri, S.D.; Singh, M.K., (2000). Color removal from synthetic dye waste water using a bioadsorbent. Water Air Soil Pollut.,120, 283-288.

Lambert, S.D.; Graham, N.J.D.; Sollars, C.J.; Flower, G.D., (1997). Evaluation of inorganic adsorbents for the removal of problematic textile dyes and pesticides. Water Sci. Tech. 36, 173-177.

Liversidge, R.M.; Lloyd, G.J.; Wase, D.A.J.; Forster, C.F., (1997). Removal of basic blue 41 dye from aqueous solution by linseed cake. Proc. Biochem., 32(6), 473476.

Low, K.S.; Lee, C.K.; Tan, B.F., (2000). Quaternised wood as sorbent for reactive dyes. Appl. Biochem. Biotechnol. 87, 233-239.

Low, K.S.; Lee, C.K., (1997). Quaternized rice husk as sorbent for reactive dyes. Bioresur. Tech., 61(2), 121126.

McKay, G., (1981). Design models for adsorption systems in wastewater treatment. J. Chem Tech. Biotech., 31, 717-722.

McKay, G.; Otterburn, M.S.; Sweeney, A.G., (1985). Fullers earth and fired clay as adsorbents for dye stuffsequilibrium and rate studies. Water Air Soil Pollut., 24, 147-151.

McMullan, G.; Meehan, C.; Conneely, A.; Kirby, N.; Robinson, T.; Nigam, P.; Banat, I.M.; Marchant, R.; Smyth, W.F., (2001). Microbial decolorisation and degradation of textile dyes. Appl. Microbiol. Biotechnol., 56, 81-88.

Metcalf and Eddy Inc., (1991). Wastewater Engineering,

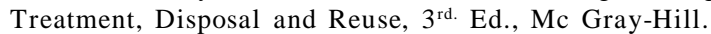

Molla, A.H.; Robinson, C.W., (1996). Pentachlorophenol adsorption and desorption characteristic of granular activated carbon. Water Res., 30 (12), 2901-2910.

Nasser, N.M.; El-Geundi, M., (1991). Comparative cost of color removal from textile effluents using natural adsorbents. J. Chem Tech. Biotech. 50, 257-262.

Netpradita, S.; Thiravetyanb, P.; Towprayoon, S., (2003). Application of waste metal hydroxide sludge for adsorption of azo reactive dyes. Water Res., 37, 763-767.

Perineau, F.; Molinier, J.; Gaset, A., (1982). Adsorption of ionic dyes onto charred plant-material, J. Chem. Tech. Biotech., 32, 749-755.

Rahman, M.S.; Islam, M.A.; Azad, A.K., (1999). Potentiality of rice husk ash and additives for the removal of congo red from wastewater, B.Sc.Engg thesis, Department of Chemical Engineering \& Polymer Science, Shah Jalal University of Science and Technology, Sylhet.

Robinson, T.; Chandran, B.; Nigam, P., (2002). Removal of dyes from a synthetic textile dye effluent by Biosorption on apple pomace and wheat straw. Water Res., 36, 28242830 . 
Robinson, T.; McMullan, G.; Marchant, R.; Nigam, P., (2001). Remediation of dyes in textile effluent: a critical review on current treatment technologies with a proposed alternative. Bioresour. Tech., 77, 247-253.

Sadi, M.; Alam, S., (1997). Analysis of specific types of locally available minerals. Analytical and environmental section, Department of Chemistry, Shah Jalal University of Science and Technology, Sylhet
Sethuraman, V.V.; Raymahashay, B.C., (1985). Color removal by clay minerals; kinetic study of adsorption of cationic and anionic dyes. Indian J. Tech., 9, 643-649.

Singh, V.N.; Panday, K. K., Prasad, G., (1984). Removal of congo red by Wallastonite. Indian J. Tech., 22, 70-74.

\section{AUTHOR (S) BIOSKETCHES}

Mumin, M. A., B.Sc. Eng., is an assistant professor in the Department of Chemical Engineering and Polymer Science, Shah Jalal University of Science and Technology, Sylhet-3114, Bangladesh.

Email: mumin-cep@sust.edu

Khan, M. M. R., M.Sc., Ph.D., is an associate professor in the Department of Chemical Engineering and Polymer Science, Shah Jalal University of Science and Technology, Sylhet-3114, Bangladesh.

Email:mrkhan@sust.edu

Akhter, K. F., B.Sc. Eng., is an assistant professor in the Department of Chemical Engineering and Polymer Science, Shah Jalal University of Science and Technology, Sylhet-3114, Bangladesh.

Email: molly-cep@sust.edu

Uddin, M. J., B.Sc. Eng., is an assistant professor in the Department of Chemical Engineering and Polymer Science, Shah Jalal University of Science and Technology, Sylhet-3114, Bangladesh and a PhD Research student in Nanotechnology at the University of Turino, Italy. Email: engr_mjuddin@yahoo.com

This article should be referenced as follows:

Mumin, M. A.; Khan, M. M. R.; Akhter, K. F.; Uddin,M. J., (2007). Potentiality of open burnt clay as an adsorbent for the removal of Congo red from aqueous solution. Int. J. Environ. Sci. Tech., 4 (4), 525-532. 